\title{
Incorporation of Ions into Giant Molybdenum-oxide Cluster as a General Phenomenon
}

\author{
Al-Ameen Bariz Omarali \\ Department of Chemistry, College of Science, Al-Mustansiriya University, Baghdad-Iraq. \\ Corresponding Author: hero_802007@uomustansiriyah.edu.iq
}

\begin{abstract}
In spite of the integration and concomitant release of all $16\left\{\mathrm{Mo}_{1}\right\}$ (necessary for ions Recently, the integration of different kinds of matter into giant wheel-shaped molybdenum-oxide clusters has been investigated with so-called chemical adaptability phenomenon. This refers to the integration of a large number of appropriate cations and anions even of the large "salt like" $\left\{\mathrm{M}\left(\mathrm{SO}_{4}\right)\right\} 16$ rings $\left(\mathrm{M}=\mathrm{K}^{+}\right.$or $\left.\mathrm{NH}^{+}\right)$based on the cooperative/synergetic activation of silent receptor sites. An even more remarkable consequence of the flexibility behavior of the molecular giant wheel-shaped molybdenum-oxides of the type $\left\{\mathrm{Mo}_{176}\right\}$ and $\left\{\mathrm{Mo}_{154}\right\}$ : the possibility of the integration of $\mathrm{Cu}^{2+}$ as tetrahedrally coordinated divalent cations at the same wheel area. In this study and in order to make the phenomenon as a general, the incorporation of ions into giant molybdenum-oxide cluster was expanded to involve the integration of some other cations $\left(\mathrm{Fe}^{2+}, \mathrm{Co}^{2+}, \mathrm{Ni}^{2+}\right.$ or $\left.\mathrm{Zn}^{2+}\right)$ or salt like $\operatorname{ring}\left\{\mathrm{Tl}\left(\mathrm{SO}_{4}\right)\right\}_{16}$.

Uptake and almost half of the $16\left\{\mathrm{Mo}_{2}\right\}$ units the parent ring structure is maintained in the following resulting hybrids $\left\{\left(\mathrm{Mo}_{146}\right)\left(\mathrm{K}\left(\mathrm{SO}_{4}\right)\right)_{16}\right\}$ 1compound, $\left\{\left(\mathrm{Mo}_{146}\right)\left(\mathrm{NH}_{4}\left(\mathrm{SO}_{4}\right)\right)_{16}\right\} 2$ compound and $\left\{\left(\mathrm{Mo}_{146}\right)\left(\mathrm{Tl}\left(\mathrm{SO}_{4}\right)\right)_{16}\right\}$ 3. Moreover, the integrating of a tetrahedrally coordinated divalent cation like $\mathrm{Fe}^{2+}, \mathrm{Co}^{2+}, \mathrm{Ni}^{2+}$ or $\mathrm{Zn}^{2+}$ in addition to $\mathrm{Cu}^{2+}$, at the same wheel area (after releasing six $\left\{\mathrm{Mo}_{2}\right\}$-type building blocks of the parent wheel-shaped cluster) produced hybrid compounds with the general formula: $\left[\mathrm{H}_{4} \mathrm{M}_{\mathrm{n}}^{\mathrm{II}} \mathrm{Mo}_{28}{ }_{28} \mathrm{Mo}^{\mathrm{VI}}{ }_{114} \mathrm{O}_{432}(\mathrm{H} 2 \mathrm{O})_{58}\right]^{-26+2(\mathrm{n}-5)}$ (where $\mathrm{M}^{\mathrm{II}}=\mathrm{Fe}^{2+}, \mathrm{Co}^{2+}, \mathrm{Ni}^{2+}$ or $\mathrm{Cu}^{2+}, \mathrm{n}=5$, but with $\mathrm{Zn}^{2+}, \mathrm{n}=6$ ) compounds (4-8). The result corresponds to the extreme flexibility of molybdenum-oxide building block linking resulting in the formation of a huge variety of structures from "molybdate" containing solutions (a unique molybdenum-oxide diversity phenomenon). The prepared compounds were characterized by CHN, Cit.Tit for the determination of the number of the $\mathrm{Mo}^{\mathrm{V}}$ centers, spectroscopic methods (IR and UV-Vis) and X-ray crystallography (determination of the characteristic unit cell dimensions).

[DOI: $10.22401 / \mathrm{JNUS}$.21.3.01]
\end{abstract}

Keywords: Giant Molybdenum-oxide Cluster, Divalent ions $\left(\mathrm{Fe}^{+2}, \mathrm{Co}^{+2}, \mathrm{Ni}^{+2}\right.$ or $\left.\mathrm{Zn}^{+2}\right)$.

\section{Introduction}

A series of investigations has been performed after the first discovery of big wheel-shaped $\left\{\mathrm{Mo}_{154}\right\}$ and $\left\{\mathrm{Mo}_{176}\right\}$ metal-oxide clusters (tetradecameric $\left\{\mathrm{Mo}_{11}\right\}_{14}$ and hexadecameric $\left\{\mathrm{Mo}_{11}\right\}_{16}$-type structures) [4], [9], [11], [12], [15], [16], [17], [19]. (for the rough information regarding the building block of the structures of $\left\{\mathrm{Mo}_{154}\right\}$ and $\left\{\mathrm{Mo}_{176}\right\}$, see Fig.(1). 


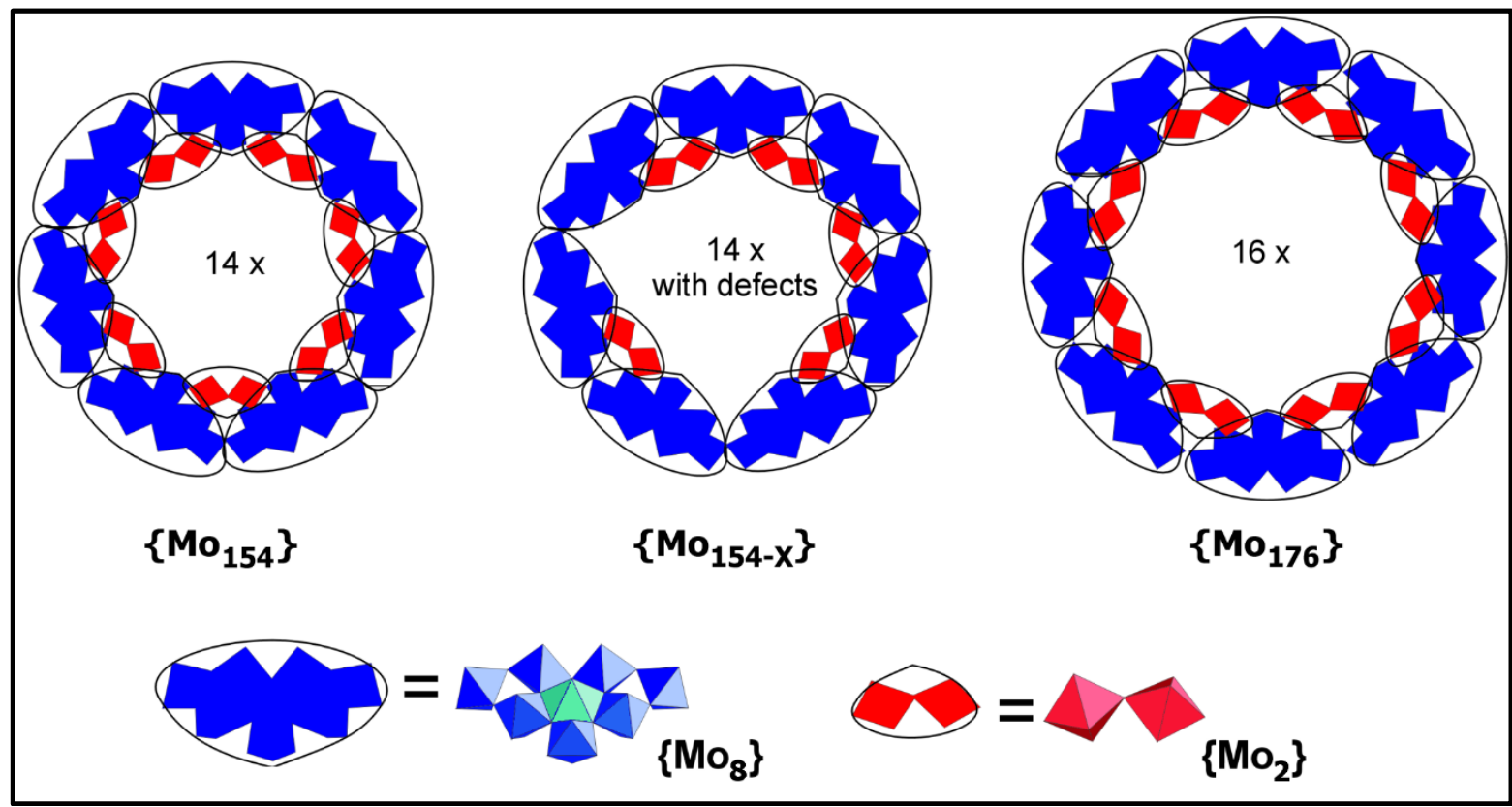

Fig. (1): shows the main building blocks of the structures of the \{Mo154\} and \{Mo176\} clusters as well as the easily released of $\{M o 2\}$ unit to form some derivatives.

These are mainly based on the versatility of the chemistry and different materials science aspects. The most highlighted of these investigations, the behaviour of giant wheel-shaped metal-oxide clusters as host (including either the cavity or compartments) for different kinds of matter exhibiting unique properties and applicationsc [7],[13],[14],[17],[31]. The molecular giant wheelshaped molybdenum-oxides of the type $\left\{\mathrm{Mo}_{176}\right\}$ and $\left\{\mathrm{Mo}_{154}\right\}$ displayed unique and fascinating flexibility behavior. The mentioned "flexibility" has its counterpart in the formation of a large variety of molybdenum-oxide structures, including giant ones. This is especially based on very different type of linking of related building blocks (interacting only weakly with each other) and their easy change in a dynamical library.

After it was mentioned in the previous works [16],[23], that a 64-membered "salt-like" containing sixteen $\mathrm{K}^{+}$and $16 \mathrm{SO}_{4}{ }^{2-}$ ions or 16 $\mathrm{NH}_{4}^{+}$and $16 \mathrm{SO}_{4}{ }^{2-}$ ions, can be integrated in the parent $\left\{\mathrm{Mo}_{176}\right\}$ wheel structure, and furthermore the integration of $\mathrm{Cu}^{+2}$ ions at the same cluster area based on appropriate/necessary changes of the host functionalities, this could now based on new results be understood as a consequence of the unprecedented "flexibility" behaviour of a giant molecular oxide. In the current work, different kinds of matter are integrated in the giant metaloxide cluster as a general phenomenon (based on chemical adaptability phenomenon). This involves the integration of a new $\left\{\mathrm{TlSO}_{4}\right\}_{16}$ ring and the incorporation of variety divalent ions like $\mathrm{Fe}^{2+}$, $\mathrm{Co}^{2+}, \mathrm{Ni}^{2+}$ or $\mathrm{Zn}^{2+}$.

\section{Experimental Part \\ 1-Materials and Techniques}

Chemicals were obtained from commercial sources and used as received: ammonium molybdate tetrahydrate $\left(9^{9} .98 \%\right.$, SigmaAldrich Co., Germany); hydrochloric acid (37\%, Sigma-Aldrich Co., Germany); iron powder-325 mesh (97\%, Aldrich Co., Germany); cobalt powder $<150 \mu \mathrm{m}(99.99 \%$, Aldrich Co., Germany); nickel powder

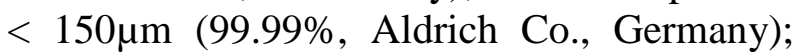

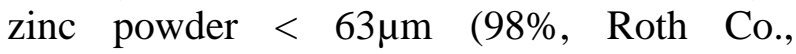
Germany); ammonium formate (97\%, SigmaAldrich Co., Germany); sodium molybdate dihydrate $(99.5 \%$, Sigma-Aldrich Co., Germany); sulfuric acid (99.999\%, Aldrich Co., Germany); sodium dithionate $(>82 \%$, Sigma Co., Germany); thallium (I) acetate (>99\%, Aldrich Co., Germany). Elemental analyses were performed by the Mikroanalytisches Labor Egmont Pascher, An der Pulvermu hle 3, Remagen. IR spectra were recorded on a Shimadzu FTIR 8400S spectrometer using $\mathrm{KBr}$ pellets, and the electronic spectra on a Shimadzu UV- 3101PC spectrophotometer. Unit cell dimensions were determined using a Bruker-AXS X8Prospector diffractometer ( $\mathrm{Cu}-\mathrm{K} \alpha$ radiation). 
2-For the synthesis of compounds (1 and 2), see results and discussion, [21],[22].

\section{3-Synthesis of 3:}

To a solution of sodium molybdate dihydrate $(3 \mathrm{~g}, 12.40 \mathrm{mmol})$ in water $(10 \mathrm{ml})$ which is acidified with sulfuric acid $(35 \mathrm{ml}$, $0.5 \mathrm{M})$, sodium dithionate (reducing agent) (0.17 g, $0.98 \mathrm{mmol})$ was added under stirring (colour turned to blue immediately). After 5 minutes, thallium (I) acetate $(0.3 \mathrm{~g}, 1.14$ mmol) was added and the mixture was further stirred in a closed flask at about $70^{\circ} \mathrm{C}$ for 60 min. After ninety-six hours, the blue precipitate was separated by filtration and washed with cold water. (Yield: $0.75 \mathrm{~g}, 28 \%$ referring to Mo). Elemental analysis (\%) calc.:Tl 13.0, Mo 37.0, Na 1.34, S 1.36; found: $\mathrm{Tl}$ 13.0, Mo 37.6, Na 1.51, S 1.60 (for $\mathrm{Mo}^{\mathrm{V}}$ values see below). Characteristic IR bands $\left(v / \mathrm{cm}^{-1}, \mathrm{KBr}\right.$ pellet$\left.): 161^{\circ}(\mathrm{m}), \delta\left(\mathrm{H}_{2} \mathrm{O}\right)\right), 1175$ (m), 111 ${ }^{\vee}(\mathrm{m}), 104 \vee(\mathrm{m}) v_{\text {as }}\left(\mathrm{SO}_{4}\right)$ triplet, 98 • (m), 95 ${ }^{\top}(\mathrm{m}), 906(\mathrm{~m}) v(\mathrm{Mo}=\mathrm{O}), 85^{\wedge}(\mathrm{w}), 75^{\circ}$ $(\mathrm{m}), 63)(\mathrm{m}), 572(\mathrm{~s})$. Characteristic visible bands $\left(\lambda / \mathrm{nm} ; \mathrm{H}_{2} \mathrm{O}\right): 705\left(\mathrm{Mo}^{\mathrm{V}} / \mathrm{Mo}^{\mathrm{VI}}\right.$ IVCT $)$ $\left(\varepsilon / \mathrm{M}^{-1} \mathrm{~cm}^{-1}=1.8 \times 10^{5}\right) .\left(\mathrm{Mo}^{\mathrm{V}}, 8.6 \%\right.$, determined by cerimetric titration corresponding to ca. 32 $\mathrm{Mo}_{(\mathrm{V})}$ centers).

4For the synthesis of compound (4), see results and discussion, [23].

\section{5- Synthesis of 5-8 compounds (general procedure):}

Metal powder and hydrochloric acid (7.0 $\mathrm{ml}, 32 \%$ ) were added to a solution of ammonium molybdate tetrahydrate $(18.20 \mathrm{~g}$, $14.73 \mathrm{mmol})$ in distilled water $(450 \mathrm{ml})$ resulting in a colour change to blue. The reaction mixture was stirred vigorously for a specific period of time in an open $500 \mathrm{ml}$ (wide-necked) conical flask. After filtration, ammonium formate $(0.70 \mathrm{~g}, 11.10 \mathrm{mmol})$ was dissolved in the deep blue filtrate and the solution was kept closed for 8 days for crystallization. The precipitated small crystals of the compound were collected by filtration and washed with ice-cold water.

\section{5-1-Spectroscopic data and other details of 5:}

Iron powder $(3.5 \mathrm{~g})$ was used as a metal powder. Reaction time: 2 hrs. Yield: $1.0 \mathrm{~g}, 5 \%$ referring to Mo. Elemental analysis (\%) calc.: $\mathrm{H}$ 3.0, Fe 1.0, N 1.3, Mo 49.1; found: $\mathrm{H} 2.9$, $\mathrm{Fe}$ 1.1, N 1.2, Mo 49.3. Characteristic IR bands $\left(v / \mathrm{cm}^{-1}, \mathrm{KBr}\right.$ pellet): $161 \leqslant(\mathrm{~m}) \delta\left(\mathrm{H}_{2} \mathrm{O}\right)$, $140 \leqslant(\mathrm{~m}) \delta \operatorname{as}\left(\mathrm{NH}_{4}^{+}\right), 98^{\top}(\mathrm{sh}), 96 \vee(\mathrm{m}), 9 \leq 0$ (sh), 90. (m) v $(\mathrm{Mo}=\mathrm{O}), 79 r(\mathrm{~m}), 74 \vee(\mathrm{m}), 67 \mathrm{r}$ $(\mathrm{sh}), 639$ (s), 558(vs). Characteristic visible bands $\left(\lambda / \mathrm{nm} ; \mathrm{H}_{2} \mathrm{O}\right): 745\left(\mathrm{Mo}^{\mathrm{V}} / \mathrm{Mo}^{\mathrm{VI}}\right.$ IVCT $)$ $\left(\varepsilon / \mathrm{M}^{-1} \mathrm{~cm}^{-1}\right.$ ca. $\left.1 . \varepsilon \times 10^{5}\right)$. (MoV, $9.5 \%$, corresponding to $28 \mathrm{Mo}^{\mathrm{V}}$ centers; cerimetric titration).

\section{5-2- Spectroscopic data and other details of} 6:

Cobalt powder $(5.0 \mathrm{~g})$ was used as a metal powder. Reaction time: 4 hrs. Yield: $1.4 \mathrm{~g}, 7 \%$ referring to Mo. Elemental analysis (\%) calc.: H 3.0, Co 1.1, N 1.3, Mo 49.1; found: H 3.0, Co 1.2, N 1.2, Mo 49.2. Characteristic IR bands $\left(\mathrm{v} / \mathrm{cm}^{-1}, \mathrm{KBr}\right.$ pellet): $161^{\top}(\mathrm{m}) \delta\left(\mathrm{H}_{2} \mathrm{O}\right)$, $1402(\mathrm{~m}) \delta_{\text {as }}\left(\mathrm{NH}_{4}{ }^{+}\right), 98^{\circ}(\mathrm{sh}), 964(\mathrm{~m}), 939$ (sh), $904(\mathrm{~m}) v(\mathrm{Mo}=\mathrm{O}), 797(\mathrm{~m}), 748(\mathrm{~m}), 670$ (sh), $636(\mathrm{~s}), 558(\mathrm{vs})$. Characteristic visible bands $\left(\lambda / \mathrm{nm} ; \mathrm{H}_{2} \mathrm{O}\right): 700\left(\mathrm{Mo}^{\mathrm{V}} / \mathrm{Mo}^{\mathrm{VI}}\right.$ IVCT $)$ $\left(\varepsilon / \mathrm{M}^{-1} \mathrm{~cm}^{-1}=1.5 \times 10^{5}\right) . \quad\left(\mathrm{Mo}^{\mathrm{V}}, \quad 9.5 \%\right.$, corresponding to $28 \mathrm{Mo}^{\mathrm{V}}$ centers; cerimetric titration).

\section{5-3- Spectroscopic data and other details of 7:}

Nickel powder $(2.0 \mathrm{~g})$ was used as a metal powder. Reaction time: 40 min. Yield: $1.5 \mathrm{~g}$, $7.4 \%$ referring to Mo. Elemental analysis (\%) calc.: $\mathrm{H}$ 3.0, Ni 1.1, N 1.3, Mo 49.1; found: $\mathrm{H}$ 3.0, Ni 1.2, $\mathrm{N}$ 1.2, Mo 49.2. Characteristic IR bands $\left(v / \mathrm{cm}^{-1}, \mathrm{KBr}\right.$ pellet): $161 \leqslant(\mathrm{~m}) \delta\left(\mathrm{H}_{2} \mathrm{O}\right)$, $\left.140^{r}(\mathrm{~m}) \delta \mathrm{as}\left(\mathrm{NH}_{4}^{+}\right), 98^{\vee}(\mathrm{sh}), 96^{\top}(\mathrm{m}), 94\right)$ (sh), $90^{\circ}(\mathrm{m}) v(\mathrm{Mo}=\mathrm{O}), 79^{r}(\mathrm{~m}), 747$ (m), 67 ฯ $(\mathrm{sh}), 63 \leqslant(\mathrm{~s}), 557(\mathrm{vs})$. Characteristic visible bands $\left(\lambda / \mathrm{nm} ; \mathrm{H}_{2} \mathrm{O}\right): 7 \leqslant 7 \quad\left(\mathrm{Mo}^{\mathrm{V}} / \mathrm{Mo}^{\mathrm{VI}}\right.$ IVCT $)$ $\left(\varepsilon / \mathrm{M}^{-1} \mathrm{~cm}^{-1}=1.6 \times 10^{5}\right) . \quad\left(\mathrm{Mo}^{\mathrm{V}}, \quad 9.5 \%\right.$, corresponding to $28 \mathrm{Mo}^{\mathrm{V}}$ centers; cerimetric titration).

\section{5-4-Spectroscopic data and other details of 8:}

Zinc powder $(1.5 \mathrm{~g})$ was used as a metal powder. Reaction time: 3 hrs. Yield: $1.3 \mathrm{~g}$, $6.4 \%$ referring to Mo. Elemental analysis (\%) calc.: H 3.0, Zn 1.4, N 1.2, Mo 49.0; found: $\mathrm{H}$ 2.9, Zn 1.3, N 1.3, Mo 49.1 (for MoV values see below). Characteristic IR bands $\left(\mathrm{v} / \mathrm{cm}^{-1}\right.$, 
$\mathrm{KBr}$ pellet): $1617(\mathrm{~m}) \quad \delta\left(\mathrm{H}_{2} \mathrm{O}\right), 1401 \quad(\mathrm{~m})$

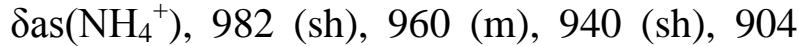
(m) $v(\mathrm{Mo}=\mathrm{O}), 799(\mathrm{~m}), 747$ (m), 671 (sh), 635 (s), 557(vs). Characteristic visible bands $\left(\lambda / \mathrm{nm} ; \mathrm{H}_{2} \mathrm{O}\right): 7 \leqslant \mathrm{~V}\left(\mathrm{Mo}^{\mathrm{V}} / \mathrm{Mo}^{\mathrm{VI}}\right.$ IVCT $)\left(\varepsilon / \mathrm{M}^{-}\right.$ $\left.{ }^{1} \mathrm{~cm}^{-1}=1.5 \times 10^{5}\right) .\left(\mathrm{Mo}^{\mathrm{V}}, 9.4 \%\right.$, corresponding to $28 \mathrm{Mo}^{\mathrm{V}}$ centers; cerimetric titration).

\section{Results and Discussion}

1-Synthesis and characterization of compounds

The below mentioned nanosized hybrid inclusion compounds 1 and 2 can be isolated according to the previous works [21],[22], (in the presence of positively and negatively charged ions with appropriate size, like $\mathrm{K}^{+}$and $\mathrm{SO}_{4}{ }^{2-}$ or $\mathrm{NH}_{4}{ }^{+}$and $\mathrm{SO}_{4}{ }^{2-}$, general structure is shown in Fig.(2) from a reaction mixture, from which usually the wheel-shaped cluster species like $\left[\left(\mathrm{MoO}_{3}\right)_{11 \mathrm{n}} \mathrm{H}_{\mathrm{n}}(\mathrm{H} 2 \mathrm{O})_{5 \mathrm{n}}\right]^{\mathrm{n}-} \equiv$ $\left[\left\{\mathrm{Mo}_{2}{ }_{2} \mathrm{O}_{5}\left(\mathrm{H}_{2} \mathrm{O}\right)_{2}\right\}\left\{\mathrm{Mo}^{\mathrm{VI} / \mathrm{V}}{ }_{8} \mathrm{O}_{26}(\mu 3-\right.\right.$ $\left.\left.\mathrm{O})_{2} \mathrm{H}\left(\mathrm{H}_{2} \mathrm{O}\right)_{3} \mathrm{Mo}^{\mathrm{VI} / \mathrm{V}}\right\}\right]_{\mathrm{n}}{ }^{\mathrm{n}-} \equiv$
$\left[\left\{\mathrm{Mo}_{2}\right\}\left\{\mathrm{Mo}_{8}\right\}\left\{\mathrm{Mo}_{1}\right\}\right]_{\mathrm{n}}^{\mathrm{n}-}(\mathrm{n}=14$ or 16$)[16]$ can be prepared in the absence of the mentioned ions (slightly different conditions).

Sixteen of the mentioned cations and anions are integrated in 1 or 2 in the form of a sixty four-membered salt-like $\left\{\mathrm{K}\left(\mathrm{SO}_{4}\right)\right\}_{16}$ ring [21] or $\left\{\mathrm{NH}_{4}\left(\mathrm{SO}_{4}\right)\right\}_{16}$ ring [22] respectively.

$\mathrm{K}_{14} \mathrm{Na}_{16}\left[\mathrm{Mo}^{\mathrm{VI}}{ }_{114} \mathrm{Mo}_{32} \mathrm{O}_{429}\left(\mathrm{H}_{2} \mathrm{O}\right)_{50}\left\{\mathrm{KSO}_{4}\right\}_{16}\right]$. ca. $500 \mathrm{H} 2 \mathrm{O} \equiv$

$\mathrm{K}_{14} \mathrm{Na}_{16}\left[\left\{\mathrm{Mo}_{2}{ }_{2} \mathrm{O}_{5}\left(\mathrm{H}_{2} \mathrm{O}\right)_{2}\right\}_{9}\left\{\mathrm{Mo}^{\mathrm{VI} / \mathrm{V}}{ }_{8} \mathrm{O}_{24}\right.\right.$

$\left.\left.\left(\mathrm{H}_{2} \mathrm{O}\right)_{2}\right\}_{16}\left\{\mathrm{KSO}_{4}\right\}_{16}\right]$. ca. $500 \mathrm{H}_{2} \mathrm{O}$ for the compound (1) [21].

$\left(\mathrm{NH}_{4}\right)_{8} \mathrm{Na}_{22}$

$\left[\mathrm{Mo}^{\mathrm{VI}}{ }_{114} \mathrm{Mo}_{32} \mathrm{O}_{429}\left(\mathrm{H}_{2} \mathrm{O}\right)_{50}\left\{\mathrm{NH}_{4} \mathrm{SO}_{4}\right\}_{16}\right] \cdot \mathrm{ca}$.

$500 \mathrm{H}_{2} \mathrm{O} \equiv$

$\left(\mathrm{NH}_{4}\right)_{8} \mathrm{Na}_{22}$

$\left[\left\{\mathrm{Mo}_{2}{ }_{2} \mathrm{O}_{5}\left(\mathrm{H}_{2} \mathrm{O}\right)_{2}\right\}_{9}\left\{\mathrm{Mo}^{\mathrm{VI} / \mathrm{V}}{ }_{8} \mathrm{O}_{24}\left(\mathrm{H}_{2} \mathrm{O}\right)_{2}\right\}_{16}\{\mathrm{NH}\right.$ $\left.\left.{ }_{4} \mathrm{SO}_{4}\right\}_{16}\right]$. ca. $500 \mathrm{H}_{2} \mathrm{O}$ for the compound (2) [22].

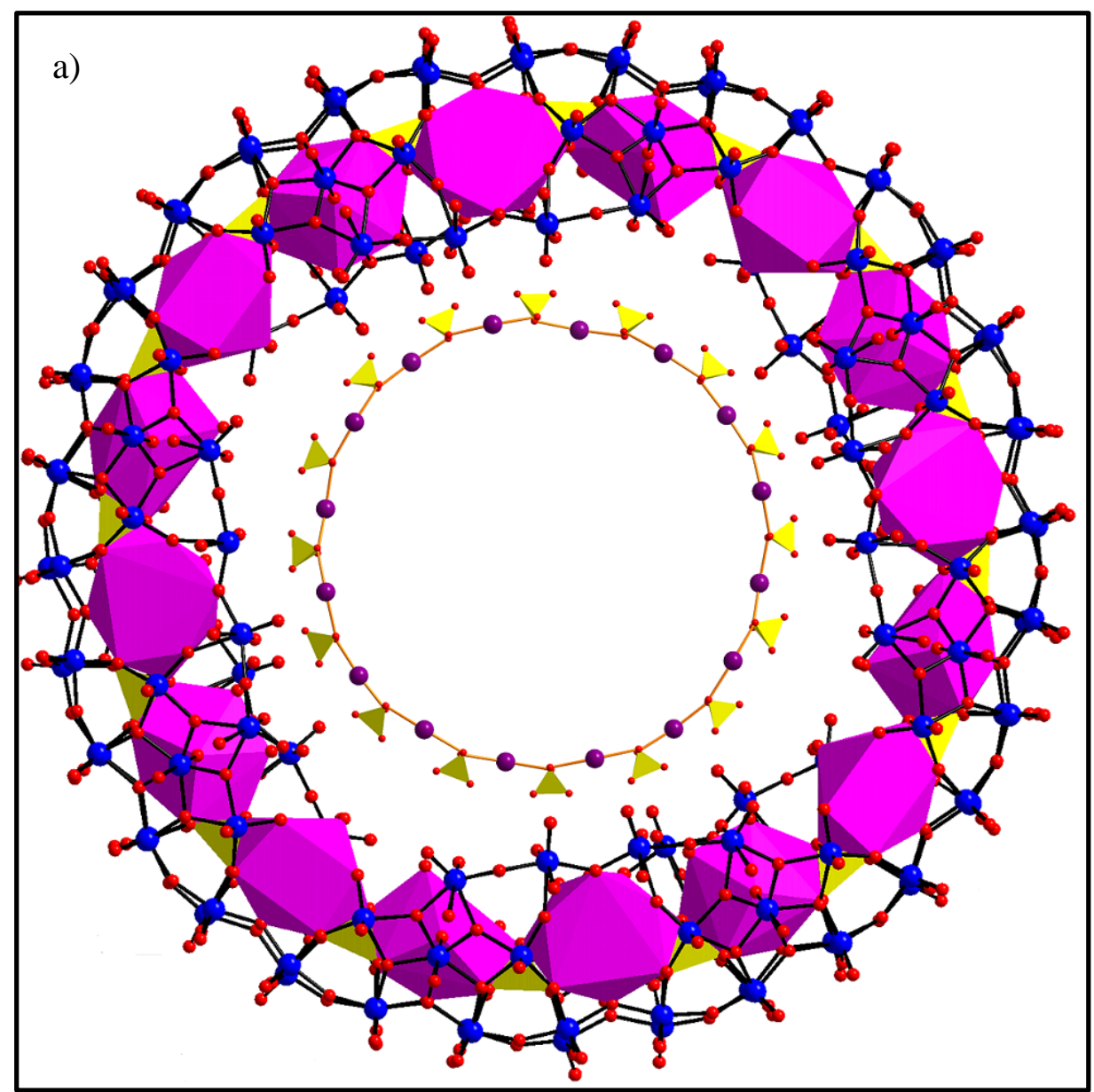




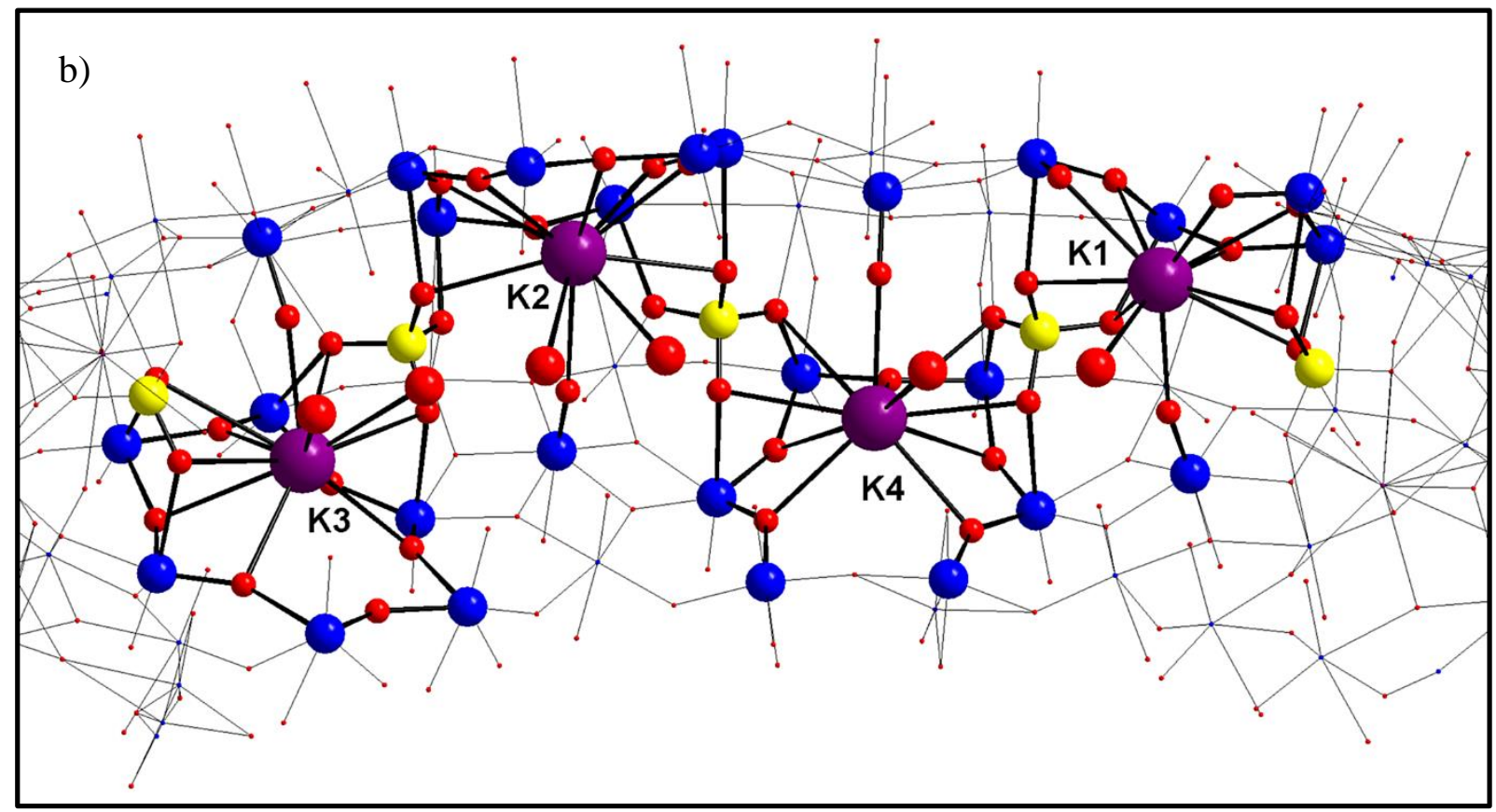

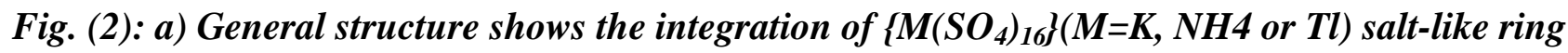
inside the wheel-shaped; $b$ ) side view shows the positions of the integrated ions in the wheel cavities (colour code: $M o$ blue, $\mathrm{O}$ red, $\mathrm{K}^{+}$violate, $S$ yellow).

The successful replacement of $16 \mathrm{~K}^{+}$or 16 $\mathrm{NH}_{4}{ }^{+}$by $16 \mathrm{Tl}^{+}$ions in compound 1 [21] or [22] which allowed now the isolation of compound 3, led together with the other mentioned discoveries - positioning of cations and anions at the same cluster area $\left(\mathrm{Mo}_{4} \mathrm{O}_{6}\right)$ to the concept of a unique flexibility character of the molecular molybdenum-oxide under consideration. Important: Parallel to the release of a large number of well-defined $\left\{\mathrm{Mo}_{\mathrm{n}}\right\}$ building blocks further necessary cluster/host building block reorganizations occur during the integration process clearly proven by the crystal structure of compound 1 [21].

$\mathrm{Na}_{22} \mathrm{Tl}_{8}\left[\mathrm{Mo}^{\mathrm{VI}}{ }_{114} \mathrm{Mo}_{32}{ }_{32} \mathrm{O}_{429}\left(\mathrm{H}_{2} \mathrm{O}\right)_{50}\left\{\mathrm{TlSO}_{4}\right\}_{16}\right]$. ca. $500 \mathrm{H}_{2} \mathrm{O} \equiv$

$\mathrm{Na}_{22} \mathrm{~T}_{18}$

$\left[\left\{\mathrm{Mo}_{2 \mathrm{VI}}{ }_{20}\left(\mathrm{H}_{2} \mathrm{O}\right)_{2}\right\}_{9}\left\{\mathrm{Mo}^{\mathrm{VI} / \mathrm{V}}{ }_{8} \mathrm{O}_{24}\left(\mathrm{H}_{2} \mathrm{O}\right)_{2}\right\}_{16}\{\mathrm{TlS}\right.$

$\left.\left.\mathrm{O}_{4}\right\}_{16}\right] \cdot$ ca. $500 \mathrm{H}_{2} \mathrm{O}$ for the compound 3

Compound 3 was characterized by some spectroscopic methods (IR and UV-Vis) in addition to the $\mathrm{CHN}$ and Cit.Tit. for the determination of the number of the $\mathrm{Mo}^{\mathrm{V}}$ centers.
An easy first spectroscopical identification of the new compound 3 is possible by comparing its characteristic IR spectrum with that of compounds 1 and 2 (a complete crystal structure for compound 1 is known [21]), for the IR spectral data see Fig.(3) and experimental section. It can be clearly seen from Fig.(3) that the spectra of the three compounds are completely identical and have exactly the same band triplet at 1175, 1117, $1047 \mathrm{~cm}^{-1}$ (these are mainly due to the splitting of the triply degenerate $v_{3}\left(F_{2}\right)$ vibration of $\left.\mathrm{SO}_{4}{ }^{2-}\right)$. This can indicates that the mentioned clusters have the same metal-oxide skeleton as well as the same type of environment of the sulphate anions. 


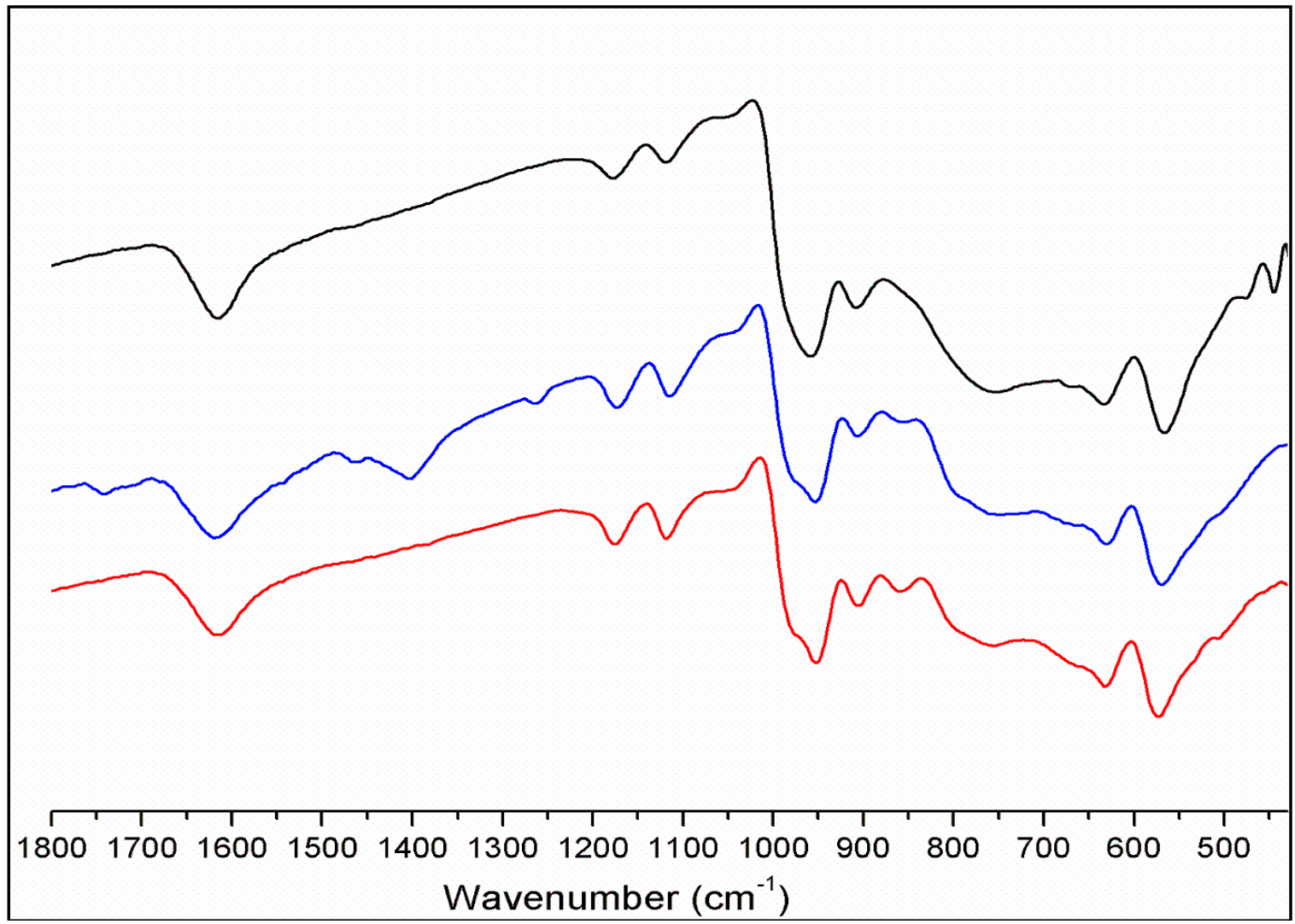

Fig. (3): Comparison of the IR spectra of 1 (black line), 2 (blue line) and 3 (red line).

It is mentioned in reference [22], that other attempts to integrate other cations like $\mathrm{Li}^{+}$or $\mathrm{Na}^{+}$instead of $\mathrm{K}^{+}, \mathrm{NH}_{4}^{+}$and $\mathrm{Tl}^{+}$have been unsuccessful and compounds are not formed (some trials with using sodium chloride instead of potassium chloride leads to the formation of the $\left\{\mathrm{Mo}_{368}\right\}$ type cluster [24],[27], while spherical $\left\{\mathrm{Mo}_{102}\right\}$ Kepleratetype cluster species [27] formed by the use of lithium chloride). We tried to optimise the conditions in order to integrate the wheel with these cations but all our attempts have been unsuccessful. This is expected as only the above mentioned type of cations and anions have the necessary sizes and functionalities needed for their integration into the metaloxide system containing flexible building blocks.

Whereas the complete parent $\left\{\mathrm{Mo}_{176}\right\}$ cluster [26],[28] ring is built up from sixteen of each of the following units: $\left\{\mathrm{Mo}_{1}\right\}-,\left\{\mathrm{Mo}_{2}\right\}-$ and $\left\{\mathrm{Mo}_{8}\right\}$-type units [29], all $16\left\{\mathrm{Mo}_{1}\right\}$ - and seven of the $\left\{\mathrm{Mo}_{2}\right\}$-type building blocks are absent in compounds 1, 2 and 3 Fig.(2). The absence of the $16\left\{\mathrm{Mo}_{1}\right\}$ units causes the space available for the positioning of $16 \mathrm{~K}^{+}$, $\mathrm{NH}_{4}^{+}$or $\mathrm{Tl}^{+}$cations below the 12 -membered
$\left\{\mathrm{Mo}_{6} \mathrm{O}_{6}\right\}$ rings/pores which can, in principle, act as cation receptors like in the often studied Keplerates $\quad\left\{\mathrm{M}_{72} \mathrm{M}_{30}^{\prime}\right\} \quad$ exhibiting 20 $\left\{\mathrm{M}_{3} \mathrm{O}_{6} \mathrm{M}_{3}^{\prime}\right\}$ pores $\left(\mathrm{M}=\mathrm{Mo}, \mathrm{W} ; \mathrm{M}^{\prime}=\mathrm{Fe}, \mathrm{V}\right)$ (For more details see references [5],[8],[33].

The cation incorporation in the present case is synergetically supported by the abundance of the negatively charged $\mathrm{SO}_{4}{ }^{2-}$ anions. Each of the 16 cations is coordinated to two $\mathrm{SO}_{4}{ }^{2-}$ ions and to skeleton $\mathrm{O}^{2-}$ as well as $\mathrm{H}_{2} \mathrm{O}$ ligands. As the $\mathrm{K}^{+}$cations are located below the $\left\{\mathrm{Mo}_{6} \mathrm{O}_{6}\right\}$ rings (based on the crystal structure of compound 1), (for instant see Fig.(2)), we can refer to their integration into the molecular molybdenum-oxide. The absence of some of the easily releasable $\left\{\mathrm{Mo}_{2}\right\}$ groups as part of the $\left\{\mathrm{Mo}_{6} \mathrm{O}_{6}\right\}$ rings/pores causes non-equivalent sites for the cations which has been proven by X-ray crystallography for compound 1 (for more details see references [21],[22].

On the other hand and according to the previous report [23], the reduction of an acidified aqueous polymolybdate solution with copper powder leads to the crystalline compound $\leqslant$. 
$\left(\mathrm{NH}_{4}\right)_{26}\left[\left(\mathrm{H}_{4} \mathrm{Cu}_{5}{ }_{5} \quad \mathrm{Mo}_{28}{ }_{28} \mathrm{Mo}^{\mathrm{VI}}{ }_{114} \mathrm{O}_{432}\left(\mathrm{H}_{2} \mathrm{O}\right)_{58}\right]\right.$ ca. $300 \mathrm{H} 2 \mathrm{O} \equiv$

$\left(\mathrm{NH}_{4}\right)_{26}\left[\left\{\mathrm{Mo}_{2}^{\mathrm{VI}} \mathrm{O}_{5}\left(\mathrm{H}_{2} \mathrm{O}\right)_{2}\right\}_{8}\left\{\mathrm{Mo}^{\mathrm{VI} / \mathrm{V}}{ }_{8} \mathrm{O}_{26}\left(\mu_{3-}\right.\right.\right.$ $\left.\left.\mathrm{O})_{2} \mathrm{Xi}\left(\mathrm{H}_{2} \mathrm{O}\right)_{3} \mathrm{Mo}^{\mathrm{VI} / \mathrm{V}}\right\}_{14}\right] \cdot$ ca. $300 \mathrm{H} 2 \mathrm{O},\left(\sum \mathrm{Xi}=\right.$ $4 \mathrm{H}+5 \mathrm{Cu})$ for compound 4 [23].

As described earlier [23], the crystal structure of compound 4 shows a cluster anion with the mentioned general formula. The structure of this compound is considered to be as a derivative of the parent $\left\{\mathrm{Mo}_{154}\right\}$ cluster: $\left\{\mathrm{Mo}_{154}\right\} \equiv\left\{\mathrm{Mo}_{8}\right\}_{14}\left\{\mathrm{Mo}_{1}\right\}_{14}\left\{\mathrm{Mo}_{2}\right\}_{14}$ [15],[17],[18]. Compound 4 lacks six $\left\{\mathrm{Mo}_{2}\right\}-$ type building blocks comparison with $\left\{\mathrm{Mo}_{154}\right\}$ cluster. Furthermore, $\mathrm{Cu}^{2+}$ ion in compound 4 is found to be incorporated within the $\mathrm{Mo}_{4} \mathrm{O}_{6}$ cavity (spanned by four oxygen atoms:two $\mu 3$ and two terminal), see Fig.(4). pH factor was found to play a major role in the synthesis of such clusters. It is well known that $\mu_{3}-\mathrm{O}$ atom is rather acidic and with high acidic conditions, the maximum 14-fold protonation of the tetradecameric cluster is obtained [15] (the $14 \mathrm{H}$ atoms of the parent $\left\{\mathrm{Mo}_{154}\right\}$ cluster which are bonded to one of the two abovementioned $\mu_{3}-\mathrm{O}$ atoms that form the cavities).

As the $\mathrm{pH}$ value increases (due to the buffering with $\mathrm{HCOONH}_{4}$ ) the degree of protonation of $\mu_{3}-\mathrm{O}$ atom decreases and consequently increases the possibility of $\mathrm{Cu}^{2+}$ coordination to the basic $\mu_{3}-\mathrm{O}$ atoms. In this context, compounds (5-8) were obtained from the reduction of an acidified aqueous polymolybdate solution with other metal powders like iron, cobalt, nickel and zinc.

The reaction of metal powder with polymolybdate in acidic medium is differ from metal to another, for example, in case of copper, half an hour was so sufficient to complete the whole reaction, including the reduction process, wheel formation and metal ion incorporation. But regarding other metals, several hours needed for the reaction (the reaction time of each reaction was optimized, see experimental section).

$\left(\mathrm{NH}_{4}\right)_{26} \quad\left[\left(\mathrm{H}_{4} \mathrm{Fe}^{\mathrm{II}}{ }_{5} \quad \mathrm{Mo}_{28}{ }_{28} \mathrm{Mo}^{\mathrm{VI}}{ }_{114} \mathrm{O}_{432}\left(\mathrm{H}_{2} \mathrm{O}\right)_{58}\right]\right.$ ca. $300 \mathrm{H} 2 \mathrm{O} \equiv$

$\left(\mathrm{NH}_{4}\right)_{26}\left[\left\{\mathrm{Mo}_{2}{ }_{2} \mathrm{O}_{5}\left(\mathrm{H}_{2} \mathrm{O}\right)_{2\} 8}\left\{\mathrm{Mo}^{\mathrm{VI} / \mathrm{V}}{ }_{8} \mathrm{O}_{26}\left(\mu_{3^{-}}\right.\right.\right.\right.$

$\left.\left.\mathrm{O})_{2} \mathrm{Xi}\left(\mathrm{H}_{2} \mathrm{O}\right)_{3} \mathrm{Mo}^{\mathrm{VI} / \mathrm{V}}\right\}_{14}\right] \cdot$ ca. $300 \mathrm{H} 2 \mathrm{O},\left(\sum \mathrm{Xi}=\right.$ $4 \mathrm{H}+5 \mathrm{Fe}$ ) for compound 5

$\left(\mathrm{NH}_{4}\right)_{26}\left[\left(\mathrm{H}_{4} \mathrm{Co}_{5}{ }_{5} \mathrm{Mo}_{28}{ }_{28} \mathrm{Mo}^{\mathrm{VI}}{ }_{114} \mathrm{O}_{432}\left(\mathrm{H}_{2} \mathrm{O}\right)_{58}\right]\right.$ ca. $300 \mathrm{H} 2 \mathrm{O} \equiv$
$\left(\mathrm{NH}_{4}\right)_{26}\left[\left\{\mathrm{Mo}_{2}^{\mathrm{VI}} \mathrm{O}_{5}\left(\mathrm{H}_{2} \mathrm{O}\right)_{2}\right\}_{8}\left\{\mathrm{Mo}^{\mathrm{VI} /{ }_{8}} \mathrm{O}_{26}\left(\mu_{3}-\right.\right.\right.$ $\left.\left.\mathrm{O})_{2} \mathrm{Xi}\left(\mathrm{H}_{2} \mathrm{O}\right)_{3} \mathrm{Mo}^{\mathrm{VI} / \mathrm{V}}\right\}_{14}\right] \cdot$ ca. $300 \mathrm{H} 2 \mathrm{O},\left(\sum \mathrm{Xi}=\right.$ $4 \mathrm{H}+5 \mathrm{Co}$ ) for compound 6

$\left(\mathrm{NH}_{4}\right)_{26}\left[\left(\mathrm{H}_{4} \mathrm{Ni}^{\mathrm{iI}}{ }_{5} \mathrm{Mo}_{28}{ }_{28} \mathrm{Mo}^{\mathrm{VI}}{ }_{114} \mathrm{O}_{432}\left(\mathrm{H}_{2} \mathrm{O}\right)_{58}\right]\right.$

ca. $300 \mathrm{H} 2 \mathrm{O} \equiv$

$\left(\mathrm{NH}_{4}\right)_{26}\left[\left\{\mathrm{Mo}_{2}{ }_{2} \mathrm{O}_{5}\left(\mathrm{H}_{2} \mathrm{O}\right)_{2}\right\}_{8}\left\{\mathrm{Mo}^{\mathrm{VI} / \mathrm{V}}{ }_{8} \mathrm{O}_{26}\left(\mu_{3-}\right.\right.\right.$

$\left.\left.\mathrm{O})_{2} \mathrm{Xi}\left(\mathrm{H}_{2} \mathrm{O}\right)_{3} \mathrm{MoVI} / \mathrm{V}\right\}_{14}\right] \cdot$ ca. $300 \mathrm{H}_{2} \mathrm{O},\left(\sum \mathrm{Xi}=\right.$

$4 \mathrm{H}+5 \mathrm{Ni}$ ) for compound 7

$\left(\mathrm{NH}_{4}\right)_{24}\left[\left(\mathrm{H}_{4} \mathrm{Zn}_{6}{ }_{6} \mathrm{Mo}_{28}{ }_{28} \mathrm{Mo}^{\mathrm{VI}}{ }_{114} \mathrm{O}_{432}\left(\mathrm{H}_{2} \mathrm{O}\right)_{58}\right]\right.$

ca. $300 \mathrm{H} 2 \mathrm{O} \equiv$

$\left(\mathrm{NH}_{4}\right)_{24}\left[\left\{\mathrm{Mo}_{2}{ }_{2} \mathrm{O}_{5}\left(\mathrm{H}_{2} \mathrm{O}\right)_{2}\right\}_{8}\left\{\mathrm{Mo}^{\mathrm{VI} / \mathrm{V}}{ }_{8} \mathrm{O}_{26}\left(\mu_{3^{-}}\right.\right.\right.$

$\left.\left.\mathrm{O})_{2} \mathrm{Xi}\left(\mathrm{H}_{2} \mathrm{O}\right)_{3} \mathrm{Mo}^{\mathrm{VI} / \mathrm{V}}\right\}_{14}\right] \cdot$ ca. $300 \mathrm{H}_{2} \mathrm{O},\left(\sum \mathrm{Xi}=\right.$ $4 \mathrm{H}+6 \mathrm{Zn}$ ) for compound 8 . 

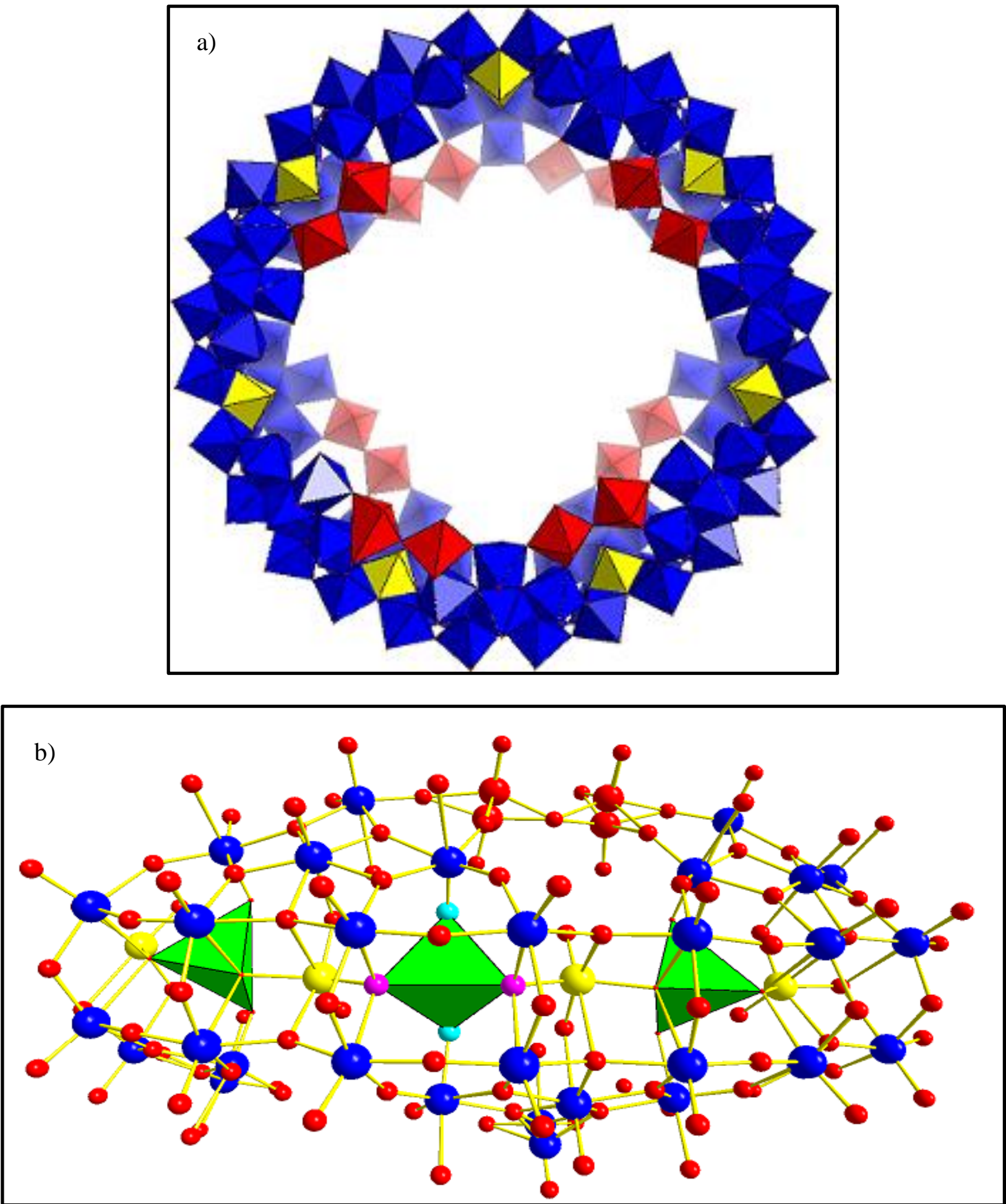

Fig. (4): a) General structure of the $\left\{M o_{142}\right\}$ type cluster shows the defect of some of $\left\{M o_{2}\right\}$ units

(colour code: $\left\{\mathrm{Mo}_{8}\right\}$ blue, $\left\{\mathrm{Mo}_{2}\right\}$ red, $\left\{\mathrm{Mo}_{1}\right\}$ yellow; b) side view shows the integration of the tetrahedrally coordinated cations $\left(\mathrm{M}^{2+}: \mathrm{Cu}^{2+}, \mathrm{Fe}^{2+}, \mathrm{Co}^{2+}, \mathrm{Ni}^{2+}\right.$ or $\left.\mathrm{Zn}^{2+}\right)$ in the $\left\{\mathrm{Mo}_{4} \mathrm{O}_{6}\right\}$ segment of the molybdenum-oxide wheel. The four oxygen atoms (coordinated to $\mathrm{M}^{2+}$ ) of the middle part of side view are enlarged and highlighted with different colours for clarity: $\mu_{3}-O$ purple, terminal-O cyan, other colour: $\mathrm{O}$ red, Mo blue, $\left\{\right.$ Mo\}1 yellow, $\mathrm{M}^{2+}$ green tetrahedron).

These compounds were characterized by spectroscopic methods (IR and UV-Vis), elemental analysis and X-ray crystallography for the determination of the characteristic unit cell practically identical to that of compound 4, see Table (1) (The isostructural compounds exhibiting the same characteristic unit cell dimensions crystallize in the same space group 
$\mathrm{C} 2 / \mathrm{m})$. Furthermore, the number of the MoV centers was determined using cerimetric titration.

As usual, an easy first spectroscopical identification of the new compounds (5-8) is possible by comparing the characteristic IR spectra of these compounds with that of 4 for which the complete crystal structure is known. It can be clearly seen from Fig.(5) that the IR spectra of these compounds are almost identical. This may indicates that the mentioned clusters have the same metal-oxide skeleton.

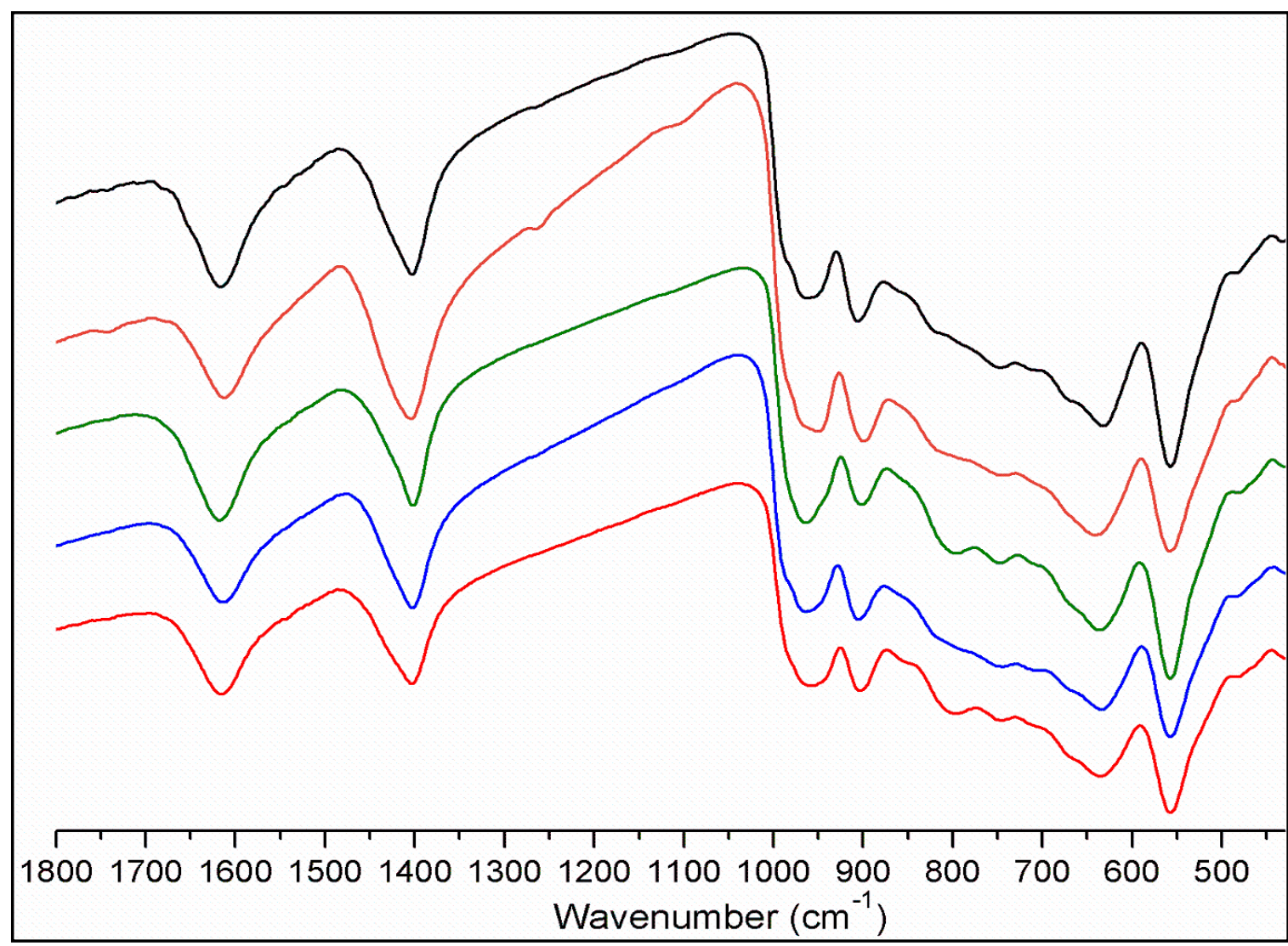

Fig. (5): Comparison of the IR spectra of 4 (black line), 5 (orange line), 6 (green line), 7 (blue line) and 8 (red line). 
Al-Ameen Bariz Omarali 


\section{Conclusions}

There are two major aspects of the present work. The first refers to the unique formation of the 64-membered "salt like" ring systems of the type $\left\{\mathrm{Tl}\left(\mathrm{SO}_{4}\right)\right\}_{16}$ and integration into the giant metal oxide cluster similarly to that of $\left\{\mathrm{M}\left(\mathrm{SO}_{4}\right)\right\}_{16} \quad\left(\mathrm{M}=\mathrm{K}\right.$ or $\left.\mathrm{NH}_{4}\right)$ (so called: chemical adaptability phenomenon). The second refers to the unprecedented "flexibility" behaviour of a nanosized giant molecular metal-oxide material in a general sense. In this context we can refer besides to the integrations of "large salt-like units" to the unprecedented option of integrations of anions and cations at the same cluster areas. This refers to the $\left\{\mathrm{Mo}_{4} \mathrm{O}_{6}\right\}$-type unit (occurring in the same way in the larger and smaller wheel) in which tetrahedrally coordinated $\mathrm{Cu}^{2+}, \mathrm{Fe}^{2+}$, $\mathrm{Co}^{2+}, \mathrm{Ni}^{2+}, \mathrm{Zn}^{2+}$ as well as $\mathrm{SO}_{4}{ }^{2-}$ ions can get positioned. It found that the cations and anions should have the necessary sizes and functionalities in order to get integrated into the metal-oxide system containing flexible building blocks. Furthermore, the $\mathrm{pH}$ value of the solution has a major role in the synthesis of such hybrid compounds. As the $\mathrm{pH}$ value increases (due to the buffering with $\mathrm{HCOONH}_{4}$ ) the degree of protonation of $\mu_{3}-\mathrm{O}$ atom decreases and consequently increases the possibility of cations coordination to the basic $\mu_{3}-\mathrm{O}$ atoms.

\section{References}

[1] Akutagawa, T., Jin, R., Tunashima, R., Noro, S-I., Cronin, L., Nakamura, T., 2008. Langmuir 24, 231.

[2] Alam, M., Kim, Y. S., Ogawa, S., Tsuda, A., Ishii, N., Aida, T., 2008. Chem. Int. Ed. 47, 2070.

[3] Clemente-León, M., Ito, T., Yashiro, H., Yamase, T., Coronado, E., 2007. Langmuir 23, 4042.

[4] Cronin, L., Müller, A., 2012. Chem. Soc. Rev. 41, 7333.

[5] Floquet, S., Brun, S., Lemonnier, J-F., Henry, M., Delsuc, M-A., Prigent, Y., Cadot, E., Taulelle, F., 2009. J. Am. Chem. Soc. 131, 17254.

[6] Gouzerh, P., Che, M., 2006. Actual. Chim. 298, 9.

[7] Imai, H., Akutagawa, T., Kudo, F., Ito, M., Toyoda, K., Noro, S-I., Cronin, L., Nakamura, T., 2009. J. Am. Chem. Soc.
131, 13578.

[8] Kögerler, P., Tsukerblat, B., Müller, A., 2010. Dalton Trans. 39, 21.

[9] Long, D. L., Tsunashima, R., Cronin, L., 2010. Angew. Chem. Int. Ed. 49, 1736.

[10] Liu, T., Diemann, E, Li , H., Dress, A. W., Müller, A., 2003. Nature 426, 59.

[11] Long, D-L., Cronin, L., 2006. Chem. Eur. J. 12, 3698.

[12] Long, D-L., Burkholder, E., Cronin, L., 2007. Chem. Soc. Rev. 36, 105.

[13] Merca, A., Garai, S., Bögge, H., Haupt, E.T., Ghosh, A., López, X., Poblet, J. M., Averseng, F., Che, M,, Müller, A., 2013. Angew. Chem. Int. Ed. 52, 11765.

[14] Miras, H. N., Cooper, G. J., Long, D-L., Bögge, H., Müller, A., Streb, C., Cronin, L., 2010. Science 327, 72.

[15] Müller, A., Serain, C., 2000. Acc. Chem. Res. 33, 2.

[16] Müller, A., Gouzerh, P., 2012. Chem. Soc. Rev. 41, 7431.

[17] Müller, A., Kögerler, P., Kuhlmann, C., 1999. Chem. Commun. 1347.

[18] Müller, A., Kögerler, P., Bögge, H., 2000. Bonding 96, 203.

[19] Müller, A., Peters, F., Pope, M. T., Gatteschi, D., 1998. Chem. Rev. 98, 239.

[20] Müller, A., Shah, S. Q., Bögge, H., Schmidtmann, M., 1999. Nature 397, 48.

[21] Müller, A., Toma, L., Bögge, H., Schmidtmann, M., Kögerler, P., 2003. Chem. Commun. 2000.

[22] Müller, A., Merca, A., Al-Karawi, A. J. M., Garai, S., Bögge, H., Hou, G., Wu, L., Haupt, E. T., Rehder, D., Haso, F., 2012. Chem. Eur. J. 18, 16310.

[23] Müller, A., Krickemeyer, E., Bögge, H., Schmidtmann, M., Kögerler, P., Rosu, C., Beckmann, E. 2001. Angew. Chem. Int. Ed. 40, 4034.

[24] Müller, A., Beckmann, E., Bögge, H., Schmidtmann, M., Dress, A., 2002. Angew. Chem. Int. Ed. 41, 1162.

[25] Müller, A., Botar, B., Das, S. K., Bögge, H., Schmidtmann, M., Merca, A., 2004. Polyhedron 23, 2381.

[26] Müller, A., Krickemeyer, E., Bögge, H., Schmidtmann, M., Beugholt, C., Kögerler, P., Lu, C., 1998. Angew. Chem. Int. Ed. 37, 1220.

[27] Müller, A., Das, S. K., Krickemyer, E., 
Kuhlmann, C., 2004. Inorg. Synth. 34, 191. [28] Müller, A., Koop, M., Bögge, H., Schmidtmann, M., Beugholt, C., 1998. Chem. Commun. 1501.

[29] Müller, A., Beugholt, C., Koop, M., Das, S. K., Schmidtmann, M., Bögge, H., 1999. Z. Anorg. Allg. Chem. 625, 1960.

[30] Noro, S. I., Tsunashima, R., Kamiya, Y., Uemura, K., Kita, H., Cronin, L., Akutagawa, T., Nakamura, T., 2009. Angew. Chem. Int. Ed. 48, 8703.

[31] Polarz, S., Smarsly, B., Antonietti, M., 2001. Chem Phys Chem 2, 457.

[32] Proust, A., Thouvenot, R., Gouzerh, P., 2008. Chem. Commun. 1837.

[33] Todea, A. M., Merca, A., Bögge, H., Glaser, T., Pigga, J. M., Langston, M. L., Liu, T., Prozorov, R., Luban, M., Schröder, C., 2010. Angew. Chem. Int. Ed. 49, 514.

[34] Tsuda, A., Hirahara, E., Kim, Y. S., Tanaka, H., Kawai, T., Aida, T., 2004. Angew. Chem. Int. Ed. 43, 6327.

[35] Zhong, D., Sousa, F. L., Müller, A., Chi, L., Fuchs, H., 2011. Angew. Chem. Int. Ed. 50,7018 . 